\title{
PEMBUATAN VIRGIN COCONUT OIL (VCO) DENGAN METODE ENZIMATIS MENGGUNAKAN SARI BONGGOL NANAS
}

\author{
MAKING VIRGIN COCONUT OIL (VCO) WITH ENZYMATIC METHOD \\ USING PAINAGE COMB STRATE
}

\author{
Rifdah $^{1)}$, Ani Melani ${ }^{2)}$, Aisyah Amini Reformis Intelekta ${ }^{3)}$ \\ ${ }^{1,2,3)}$ Program Studi Teknik Kimia, Fakultas Teknik, Universitas Muhammadiyah Palembang, Palembang, Indonesia \\ Corresponding Author E-mail: rifdah147@gmail.com
}

\begin{abstract}
Indonesia is a tropical country that has many islands and Indonesia is the largest coconut producing country in the world after the Philippines. This is an opportunity for the development of coconut into various useful products, for example by making coconut as a raw material for making virgin coconut oil, thereby increasing the selling value of coconut. Pure coconut oil has many advantages, namely the manufacturing process does not require expensive costs, processing is simple and not too complicated. The enzymatic method is one of the methods in the production of VCO which can produce products with higher yields. One of the enzymes that can be used is the bromelain enzyme, where this enzyme will hydrolyze the protein and make the oil separate from the water in the coconut milk emulsion. Sending coconut milk used is $200 \mathrm{ml}$ and the variables used for research are time variations, namely 24 hours, 36 hours, 48 hours, 60 hours, and also variations in the concentration of pineapple weevil extract, namely 5\%, 10\%, 15\%, and $20 \%$. The results of the research on making virgin koconut oil (VCO) with the enzymatic method using the best pineapple weevil extract according to SNI 7381:2008 is the incubation time of 24 hours and the concentration of pineapple weevil extract is $5 \%$. Where the density is $0.9150 \mathrm{~g} / \mathrm{cm}^{3}, 0.133 \%$ free fatty acids, 0.1870 , the acid number is $1.8 \mathrm{meq} / \mathrm{kg}$, and the color is clear yellow.

Keywords: Coconut, Painage Comb Strate, Enzymatic Method, VCO.
\end{abstract}

\begin{abstract}
Abstrak: Indonesia merupakan negara tropis yang memiliki banyak pulau dan Indonesia termasuk negara produsen kelapa terbesar di dunia setelah Filipina. Hal ini merupakan peluang untuk pengembangan kelapa menjadi aneka produk yang bermanfaat, misalnya dengan menjadikan kelapa sebagai bahan baku pembuatan minyak kelapa murni (virgin coconut oil) sehingga menaikkan nilai jual dari kelapa. Minyak kelapa murni memiliki banyak keunggulan yaitu proses pembuatan tidak membutuhkan biaya yang mahal, pengolahan yang sederhana dan tidak terlalu rumit. Metode enzimatis adalah salah satu metode dalam produksi VCO yang dapat menghasilkan produk dengan rendemen yang lebih banyak. Salah satu enzim yang bisa digunakan adalah enzim bromelin, dimana enzim ini akan menghidrolisis protein dan membuat minyak dapat terpisah dengan air dalam emulsi santan. Kirim santan yang digunakan adalah $200 \mathrm{ml}$ dan variabel yang digunakan untuk diteliti adalah variasi waktu yaitu 24 jam, 36 jam, 48 jam, 60 jam, dan juga variasi konsentrasi ekstrak bonggol nanas yaitu 5\%,10\%,15\%, dan $20 \%$. Hasil penelitian pembuatan virgin coconut oil (VCO) dengan metode enzimatis menggunakan sari bonggol nanas yang terbaik sesuai SNI 73812008 adalah pada waktu inkubasi 24 jam dan konsentrasi ekstrak bonggol nanas $5 \%$. Dimana massa jenisnya adalah $0,9150 \mathrm{~g} / \mathrm{cm}^{3}$, asam lemak bebas 0,133\%, bilangan asam 0,1870, bilangan peroksida 1,8 meq/kg, dan untuk warnanya kuning bening.

Kata kunci: Kelapa, Sari Bonggol Nanas, Metode Enzimatis, VCO.
\end{abstract}

\section{PENDAHULUAN}

Indonesia merupakan negara tropis yang memiliki banyak pulau dan Indonesia termasuk negara produsen kelapa terbesar di dunia setelah Filipina. Hampir di semua provinsi di Indonesia dijumpai tanaman kelapa (Cocos nucifera, L) yang berupa perkebunan rakyat(Rindengan dan Novarianto, 2004). Hal ini merupakan peluang untuk pengembangan kelapa menjadi aneka produk yang bermanfaat. Misalnya dengan menjadikan kelapa sebagai bahan baku pembuatan minyak kelapa murni (virgin coconut oil) sehingga menaikkan nilai jual dari kelapa.

Minyak kelapa pada umumnya dibagi menjadi dua kategori utama, yaitu RBD (Refined, Bleached, Deodorized) dan VCO (Virgin Coconut Oil). Penyebabnya adalah proses pembuatan dan pemilihan buah kelapanya, yang mempunyai kualitas , 
penampakan, rasa, bau, dan khasiatnya. Perbedaannya dapat terlihat dari RBD terbuat dari kopra (daging kelapa yang dijemur atau diasapi), sedangkan VCO terbuat dari santan kelapa segar.

\section{TEORI DASAR}

\subsection{Minyak Kelapa}

Minyak kelapa adalah minyak yang berwarna kuning pucat sampai tidak berwarna, atau lemak semi padat berwarna putih yang diperoleh dari daging buah kelapa, digunakan secara luas dalam industri makanan dan produksi kosmetika serta sabun. Minyak kelapa kaya akan asam laurat, asam lemak rantai medium. Minyak kelapa merupakan minyak yang paling stabil diantara seluruh minyak nabati (Darmoyowono, 2006 dalam Nikmah 2017).

Macam-macam minyak kelapa:

\section{Minyak kelapa komersial}

Minyak kelapa komersial (RBD) dibuat dari kopra. Hasil ekstraksi dari kopra merupakan minyak mentah dan belum dimurnikan sehingga tidak layak dikonsumsi. Hal ini disebabkan kopra tidak memperhatikan sanitasi. Produk akhir yang terbuat dari kopra adalah minyak kelapa RBD yang diproses dengan pemurnian, pemutihan dan penghilangan aroma. (Sutarmi dan Rozaline, 2005 dalam Hikmah, 2017)

2. Minyak kelapa biasa (minyak kelentik)

Minyak kelapa biasa dibuat secara tradisional umumnya sudah mengalami fermentasi selama lebih dari 12 jam. Disamping itu, warna minyak tidak bening, umumnya berwarna kuning kecoklatan mengakibatkan daya simpannyapun tidak lama, hanya sekitar dua bulan saja (Rindengan dan Novarianto, 2004).

3. Minyak kelapa murni

VCO merupakan hasil olahan kelapa yang baru berkembang dengan nilai ekonomi yang sangat tinggi, karena manfaatnya begitu besar untuk kesehatan tubuh manusia. Minyak kelapa murni merupakan bahan baku industri pangan, farmasi dan kosmetik terutama untuk perawatan tubuh. Disamping itu, dari hasil penelitian terbaru yang terkandung dalam buah kelapa, bahwa minyak kelapa murni yang beraroma gurih dan lembut yang dapat meningkatkan metabolisme tubuh serta menanggulangi berbagai penyakit.

Ada beberapa metode pembuatan virgin coconut oil ( $\mathrm{VCO}$ ) diantaranya sebagai berikut:

a. Metode pemanasan

Dengan cara pemanasan, dari santan ini akan diperoleh minyak kelapa. Umumnya suhu sekitar $100-110^{\circ} \mathrm{C}$. Suhu ini dikatakan ideal karena pada suhu tersebut air yang terdapat dalam santan akan menguap, dengan demikian protein yang berikatan dengan air akan terpecah. (Setiaji, B dan Surip, P, 2006).

b. Metode pemanasan bertahap

Dalam pemanasan bertingkat hanya menggunakan suhu sekitar $60^{\circ} \mathrm{C}-75^{\circ} \mathrm{C}$. Karena pada suhu $80^{\circ} \mathrm{C}$, protein, lemak dan antioksidan akan rusak, maka dilakukan pengukuran suhu saat dimasak dengan termometer. (Setiaji, B dan Surip, P, 2006).

c. Metode sentrifugasi

Upaya yang dilakukan untuk memutuskan ikatan lemak-protein pada santan dengan pemutaran, yaitu cara sentrifugal. Karena berat jenis minyak lebih ringan daripada air, maka setelah dilakukan sentrifugasi keduanya akan terpisah dengan sendirinya. Kecepatan putaran yang digunakan 20.000 rpm. (Setiaji, B dan Surip, P, 2006).

d. Metode pengasaman

Pengasaman merupakan cara membuat suasana emulsi (santan) dalam keadaan asam. Karena asam memiliki kemampuan untuk memutuskan ikatan lemak-protein. Asam akan mengikat senyawa yang berikatan dengan lemak. Namun asam yang dicampurkan dalam santan hanya bisa bekerja dengan maksimal pada $\mathrm{pH}$ sesuai. (Setiaji, B dan Surip, P, 2006). e. Metode fermentasi

Biakan mikrobia yang digunakan harus memiliki aktivitas proteolitik, amilolitik dan lipolitik yang berperan menghidrolisis protein, karbohidrat dan lemak (Ishwanto, 2001 dalam Ramadhani, 2010).

f. Metode enzimatis

Ikatan protein minyak yang berada fasa emulsi santan bisa juga dipecah dengan bantuan enzim. Disini yang dirusak yaitu 
proteinnya bukan lemaknya. Protein dalam ikatan lipoprotein dipecah dengan enzim protein, disebut dengan enzim protease. Beberapa jenis enzim yang bisa digunakan untuk memecah ikatan lipoprotein dalam emulsi lemak, yaitu: papain, bromelin, dan enzim protease. (Setiaji, B dan Surip, P, 2006). g. Metode penggaraman

Motode penggaraman dilakukan dengan tujuan untuk pemecahan sistem emulsi santan dengan pengaturan kelarutan protein di dalam garam. Protein yang terdapat dalam santan akan terlarut dengan adanya penambahan garam, tetapi dengan kondisi tertentu kelarutan protein akan menurun dengan peningkatan konsentrasi garam. (Setyo, P., 2005 dalam Sari, E.P. dan Andayani, 2009).

h. Metode pancingan

Cara kerja pembuatan VCO dengan pemancingan membutuhkan peralatan yang sangat sederhana. Ikatan protein-lemak yang berada pada santan diputus dengan pancingan VCO yang sudah jadi. Setelah beberapa lama didiamkan, minyak dalam santanpun akan keluar dengan sendirinya. (Setiaji, B. dan Surip, P., 2006).

\subsection{Nanas}

Nanas (Ananas comosus) adalah tumbuhan tropis dengan buah yang dapat dimakan dan tumbuhan yang paling penting secara ekonomi dalam famili Bromeliaceae. Nanas yang digunakan pada penelitian kali ini adalah nanas dari kota Prabumulih. Nanas Prabumulih dipilih karena nanas Prabumulih merupakan nanas yang cukup unggul. Nanas yang banyak dibudidayakan petani di Kota Prabumulih adalah jenis queen, dan untuk umur nanasnya sendiri sekitar 5 bulanan.

\subsection{Enzim Bromelin}

Bromelin adalah enzim proteolitik yang ditemukan pada bagian tangkai, kulit, daun, buah, maupun batang nanas (Ananas comosus) dalam jumlah yang berbeda. Bromelin adalah salah satu enzim proteolitik atau protease, yaitu enzim yang mengkatalisa penguraian protein menjadi asam amino dengan membangun blok melalui reaksi hidrolisis. Dalam pemecahan protein, ikatan peptidase terputus dengan penyisipan komponen air, $-\mathrm{H},-\mathrm{OH}$ pada rantai akhir. Sekitar setengah protein dalam nanas mengandung protease bromelin. (Donald, 1997 dalam Wuryanti, 2004).

\section{METODOLOGI PENELITIAN 3.1 Alat dan Bahan Penelitian}

Alat dan bahan yang digunakan pada penelitian ini antara lain:

a. Alat

Alat yang digunakan pada penelitian ini, yaitu: timbangan, alat parutan kelapa, saringan, corong pisah, kertas saring, klem dan statif, buret, corong kaca, gelas ukur, labu ukur, erlenmeyer, beaker glass, pipet tetes, spatula, cawan petri, neraca analitik, hot platen stirrer, piknometer, dan pipet ukur.

b. Bahan

Bahan yang digunakan pada penelitianini, yaitu: santan kelapa, buah nanas, aquadest, alkohol 95\%, kalium hidroksida, natrium hidroksida, indikator phenolphtaline, asam asetat, kloroform, kalium iodide, natrium thiosulfat, dan amylum.

\subsection{Metode Penelitian}

\section{proses berikut ini:}

1. Santan yang didapatkan dari didiamkan selama 2 jam.

2. Setelah didiamkan terbentuk dua bagian, yang dimana krim berada dibagain atas. Selanjutnya ambil krim dibagian atas sebanyak $200 \mathrm{ml}$, kemudian krim santan dimasukkan ke dalam beaker glass.

3. Kemudian tambahkan ekstrak bonggol nanas sebanyak $5 \%, 10 \%, 15 \%$, dan $20 \%$ diaduk hingga merata menggunakan stirrer selama 10 menit.

4. Setelah itu, didiamkan dengan variasi waktu 24 jam, 36 jam, 48 jam, dan 60 jam hingga terbentuk tiga lapisan, yaitu lapisan atas berupa blondo, lapisan tengah berupa minyak dan lapisan bawah berupa air. Minyak yang didapatkan disaring menggunakan kertas saring dan dianalisa. 


\section{HASIL DAN PEMBAHASAN}

\subsection{Rendemen}

Dari gambar 4.1 diketahui ekstrak bonggol nanas dan lama waktu inkubasi berpengaruh terhadap rendemen yang didapat. Semakin besar konsentrasi ekstrak bonggol nanas yang digunakan, maka akan semakin banyak VCO yang didapatkan. Hal ini terjadi disebabkan karena akan semakin banyak enzim beromelin yang terdapat pada ekstrak bonggol nanas untuk pemecahan emusi santan oleh karena itu akan semakin banyak minyak kelapa murni (virgin coconut oil) yang dihasilkan.

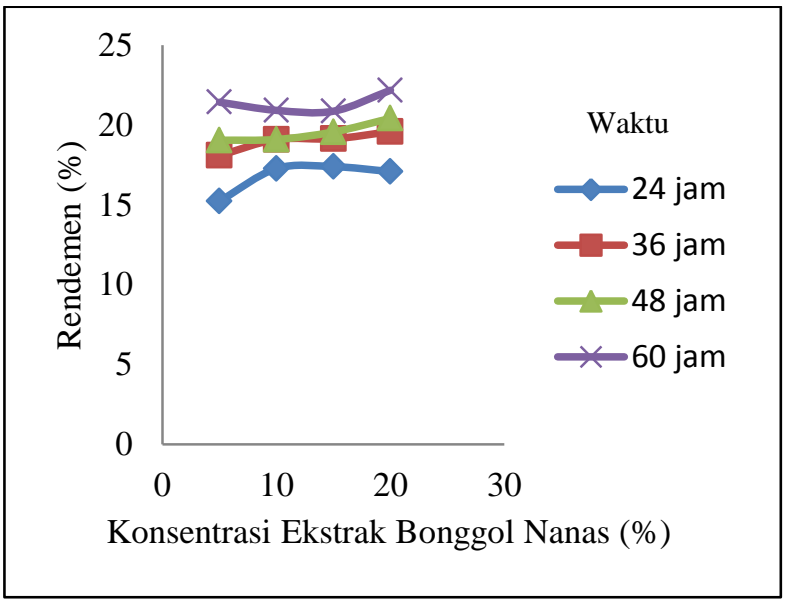

Gambar 4.1 Pengaruh Waktu dan Konsentrasi Ekstrak Bonggol Nanas Terhadap Rendemen

Lama waktu inkubasi juga berpengaruh terhadap rendemn yang dihasilkan. Semakin lama inkubasi, maka pemecahan emulsi santan akan terus berlangsung dan kecepatan reaksi hidrolisis protein semakin meningkat, sehingga menghasilkan VCO yang lebih banyak dan menyebabkan rendemennya akan semakin tinggi.

Dapat diketahui bahwa pada pembuatan VCO menggunakan ekstrak bonggol nanas, rendemen terendah terdapat pada waktu 24 jam dan konsentrasi ekstrak bonggol nanas 5\%, yaitu sebesar $15,23 \%$. Kemudian untuk rendemen tertinggi terdapat pada waktu 60 jam dan konsentrasi ekstrak bonggol nanas $20 \%$, yaitu sebesar $22,17 \%$. Rendemen yang dihasilkan semakin tinggi seiring dengan bertambahnya ekstrak bonggol nanas dan juga semakin lama waktu inkubasi.

\subsection{Densitas}

Jika dilihat dari gambar 4.2 dapat diketahui bahwa waktu inkubasi tidak berpengaruh terhadap densitas, karena densitas atau massa jenis VCO dipengaruhi oleh berat molekul dan ketidakjenuhan asam lemak minyak. Ini juga dapat terjadi karena adanya zat-zat kotoran yang dapat mempengaruhi densitas dimana zat-zat kotoran tersebut bisa saja tercampur dengan VCO dikarenakan pada saat filtrasi kertas saring yang digunakan kulitasnya kurang baik sehingga masih meloloskan zat-zat pengotor.

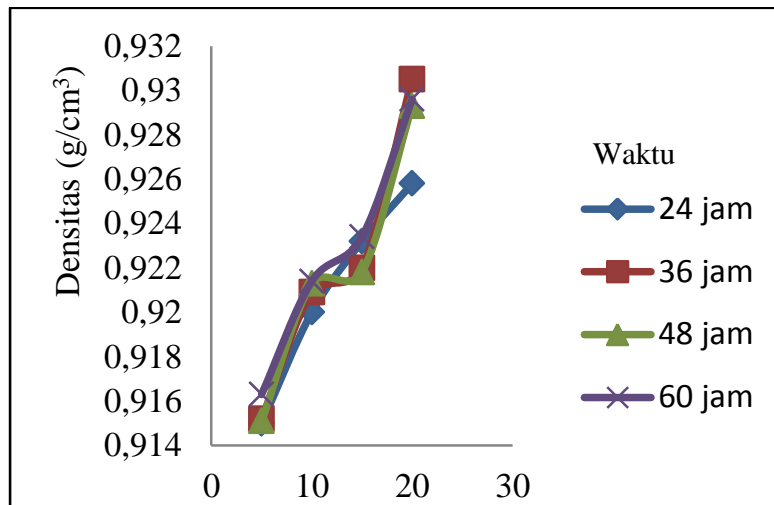

Konsentrasi Ekstrak Bonggol Nanas (\%)

Gambar 4.2 Pengaruh Waktu dan Konsentrasi Ekstrak Bonggol Nanas Terhadap Densitas

Standar yang ditetapkan untuk densitas VCO adalah antara $0,9150 \mathrm{~g} / \mathrm{cm}^{3}-0,9244$ $\mathrm{g} / \mathrm{cm}^{3}$ dari seluruh sampel VCO dapat diketahui bahwa masih ada beberapa yang memenuhi SNI. Untuk densitas yang terendah 24 jam dengan konsentrasi ekstarak bonggl nanas 5\% yang dimana densitasnya adalah $0,9150 \mathrm{~g} / \mathrm{cm}^{3}$. Sedangkan untuk densitas pada waktu inkubasi 36 jam dan konsentrasi ekstrak bonggol nanas $20 \%$ sebesar $0,9305 \mathrm{~g} / \mathrm{cm}^{3}$. Densitas tertinggi hanya pada VCO untuk variasi konsentrasi ekstrak bonggol nanas $20 \%$ untuk semua variasi lama waktu inkubasi 24 jam, 36 jam, 48 jam, dan 60 jam yang disiaptkan hasil semua tidak memenuhi standar densitas.

Konsidi tersebut berpengaruh terhadap densitas karena jika semakin besar konsentrasi ekstarak bonggol nanas, maka akan semakin rentan kotoran-kotoran yang dapat 
mempegaruhi densitas VCO. Faktor lain juga dapat disebabkan karena banyaknya enzim bromelin. Semakin banyak enzim bromelin, maka reaksi hidrolisis akan terus meningkat yang menghasilkan gliserol yang cukup banyak.

\subsection{Asam Lemak Bebas}

Asam lemak bebas atau bisa juga disebut free fatty acid (FFA) adalah asam lemak yang berada sebagai asam bebas tidak terikat berupa trigliserida. Asam lemak bebas dihasilkan oleh proses hidrolisis dan oksidasi. Sedangkan fungsi dari analisa asam lemak bebas dalam pembuatan VCO adalah untuk mengetahui kandunagan asam lemak bebas dalam VCO. Dimana semakin banyak asam lemak bebasnya, maka semakin jelek kualitas VCO tersebut.

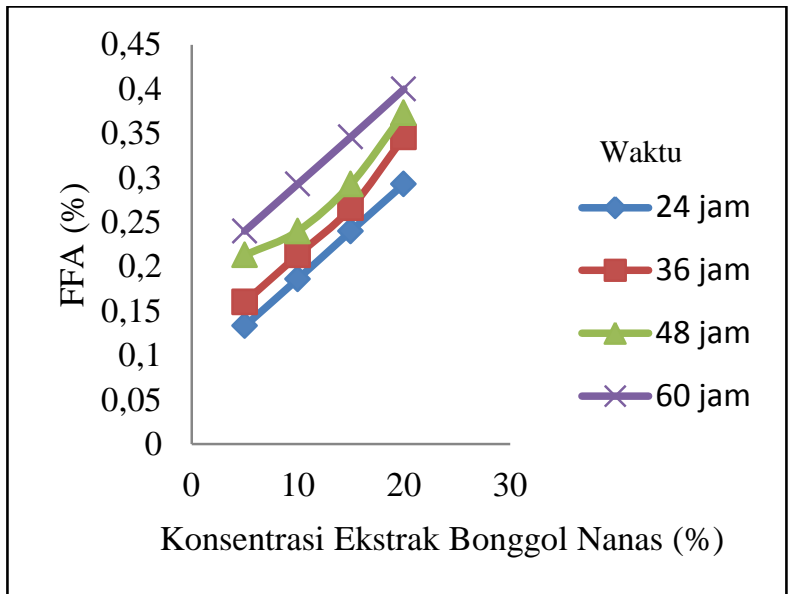

Gambar 4.3 Pengaruh Waktu dan Konsentrasi Ekstrak Bonggol Nanas Terhadap Kadar Asam Lemak Bebas

Dapat dilihat dari gambar 4.3 bahwa kandungan asam lemak bebas terendah terdapat pada waktu inkubasi 24 jam dan konsentrasi ekstrak bonggol nanas $5 \%$, dihasilkan asam lemak bebasnya sebesar $0,133 \%$. Sedangkan untuk asam lemak bebas tertinggi terdapat pada waktu inkubasi 60 jam dan konsentrasi asam lemak bebas $20 \%$, dihasilkan asam lemak bebasnya sebesar $0,40 \%$.

Seperti yang diketahui bahwa SNI virgin coconut oil untuk asam lemak bebas adalah maksimal 0,2 \%. Jika dilihat dari gambar 4.3 tidak semua sampel memenuhi standar, hanya ada tiga sampel yang memenuhi standar, yaitu pada waktu inkubasi 24 jam dengan konsentrasi ekstrak bonggol nanas $5 \%$ dan $10 \%$ serta yang ketiga adalah pada waktu inkubasi 36 jam dengan konsentrasi ekstrak bonggol nanas $5 \%$.

Pada gambar 4.3 dapat diketahui bahwa grafik terus naik. Hal ini dikarenakan kandungan asam lemak bebas dipengaruhi oleh waktu inkubasi dan konsentrasi ekstrak bonggol nanas. Semakin lama waktu inkubasi dan semakin tinggi konsentrasi ekstrak bonggol nanas, maka kandungan asam lemak bebas akan semakin meningkat, karena adanya kandungan air dalam bonggol nanas yang dapat mempercepat terjadinya proses hidrolisis VCO.

\subsection{Bilangan Asam}

Bilangan asam adalah menandakan jumlah mg $\mathrm{KOH}$ yang dibutuhkan untuk menetralkan 1 gram sampel minyak goreng. Bilangan asam menunjukkan kualitas minyak dengan semakin tinggi bilangan asam maka semakin rendah kualitas VCO. Penentuan angka bilangan asam dapat dilakukan dengan metode titrasi.

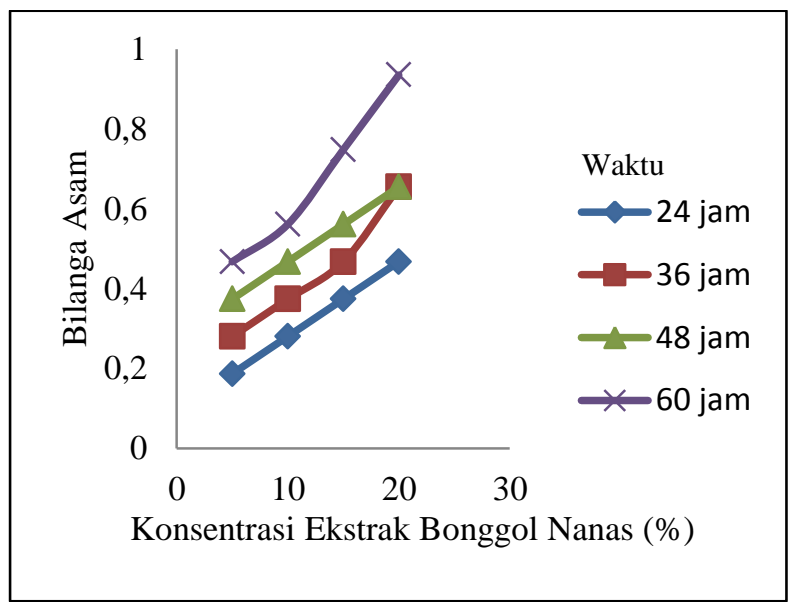

Gambar 4.4 Pengaruh Waktu dan Konsentrasi Ekstrak Bonggol Nanas Terhadap Angka Bilangan Asam

Satandar untuk bilangan asam adalah 0,5 . Setelah dilihat dari gambar 4.4 dapat diketahui bahwa banyak sampel yang sudah memenuhi standar. Pada waktu inkubasi 60 jam yang hampir semua sempelnya tidak memenuhi standar, yaitu pada konsentrasi 
ekstrak bonggol nanas $10 \%, 15 \%$, dan $20 \%$, serta pada kensentrasi ekstrak bonggol nanas $20 \%$ dengan waktu inkubasi 36 jam dan 48 jam yang tidak memenuhi standar.

Sedangkan jika dilihat dari gambar 4.4 dapat diketahui bahwa untuk angka bilangan asam terendah didapatkan pada waktu ikubasi 24 jam dengan konsentrasi ekstak bonggol nanas $5 \%$ dengan angka bilangan asamnya sebesar 0,1870. Untuk angka bilangan asam tertingginya adalah pada sampel waktu inkubasi 60 jam dengan konsentrasi ekstrak bonggol nanas $20 \%$ dengan angka bilangan asamnya sebesar 0,9350.

Berdasarkan hasil analisa yang terlihat pada gambar 4.4 terlihat dengan bertambah tingginya konsentrasi ekstrak bonggol nanas, maka semakin tinggi pula bilangan asamnya. Ini dikarenakan semakin banyak enzim beromelin yang digunakan, maka semakin tinggi hidrolisis trigliserida yang terjadi akibat kerusakan minyak atau lemak.

\subsection{Bilangan Peroksida}

Bilangan peroksida adalah bilangan yang terpenting untuk menentukan derajat kerusakan minyak. Asam lemak tidak jenuh dapat meningkatkan oksigen pada ikatan rangkapnya sehingga membentuk peroksida. Semakin tinggi bilangan peroksida, maka minyak akan lebih mudah bau. Semakin tinggi bilangan peroksida, maka semakin buruk kualitas VCO tersebut.

Jika dilihat dari gambar 4.5 dapat diketahui bahwa untuk nilai peroksida terkecil terdapat pada waktu inkubasi 24 jam dengan konsentrasi ekrstrak nanas 5\% dengan bilangan peroksida sebasar $1,8 \mathrm{meq} / \mathrm{kg}$. Sedangkan untuk nilai peroksida terbesarnya terdapat pada waktu inkubasi 60 jam dengan konsentrasi ekstrak bonggol nanas $20 \%$ diperoleh bilangan peroksida sebesar 5 $\mathrm{meq} / \mathrm{kg}$.

Standar untuk bilangan peroksida sesuai Standar Nasional Indonesia (SNI) adalah $2 \mathrm{meq} / \mathrm{kg}$. Sedangkan jika dilihat dari grafik dapat dilihat bahwa masih banyak sampel yang tidak memenuhi standar bilangan peroksida, terutama pada sampel dengan konsentrasi ekstrak bonggol nanas yang besar.
Hanya ada tiga sampel yang memenuhi standar nasional Indonesia VCO untuk bilangan peroksida terdapat pada waktu inkubasi 24 jam dengan konsentrasi ekstrak bonggol nanas 5 $\%$, dan $10 \%$, serta sampel dengan waktu inkubasi 36 jam dan konsentrasi ekstrak bonggol nanas $5 \%$.

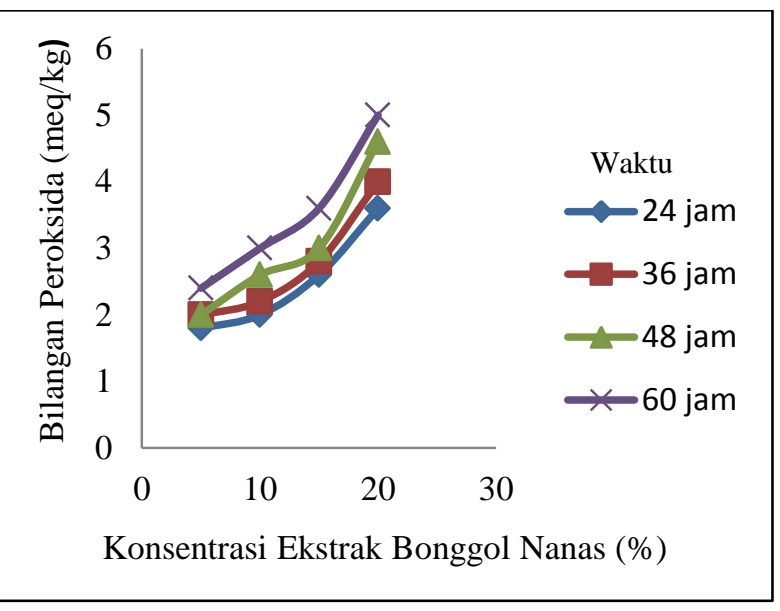

Gambar 4.5 Pengaruh Waktu dan Konsentrasi Ekstrak Bonggol nanas Terhadap Angka Bilangan Peroksida

Jika dilihat dari gambar 4.5 dapat diketahui bahwa grafik terus meningkat, atau bisa dikatakan bahwa bilangan peroksida dipengaruhi oleh waktu inkubasi dan konsentrasi ekstrak bonggol nanas. Hal ini terjadi karena ekstrak bonggol memiliki kandungan air yang dapat mempecepat hidrolisis hingga rentan untuk mengalami oksidasi.

\subsection{Analisa Organoleptik (Warna)}

Uji organoleptik atau biasa disebut uji indera atau uji sensori merupakan cara pengujian dengan menggunakan indera manusia sebagai alat utama untuk pengukuran daya penerimaan terhadap produk. Pengujian organoleptik mempunyai peranan penting dalam penerapan mutu. Pengujian organoleptik dapat memberikan indikasi kebusukan, kemunduran mutu dan kerusakan lainnya dari produk.

Karakteristik warna VCO yang sesuai Standar Nasional Indonesia adalah bening. Hal ini menandakan bahwa VCO tidak terkontaminasi oleh zat pengotor. Jika dilihat pada gambar 4.6, VCO yang dihasilkan 
dengan menambahkan ekstrak bonggol nanas adalah berwarna kuning bening. Hal ini terjadi karena warna kuning yang dimiliki oleh nanas berpengaruh terhadap VCO yang dihasilkan. Selain itu, dapat dilihat dari gambar tersebut bahwa semakin besar konsentrasi ekstrak bonggol nanas, maka semakin berwarna kuning VCO. Hal ini terjadi karena semakin banyak ekstrak nanas yang digunakan.
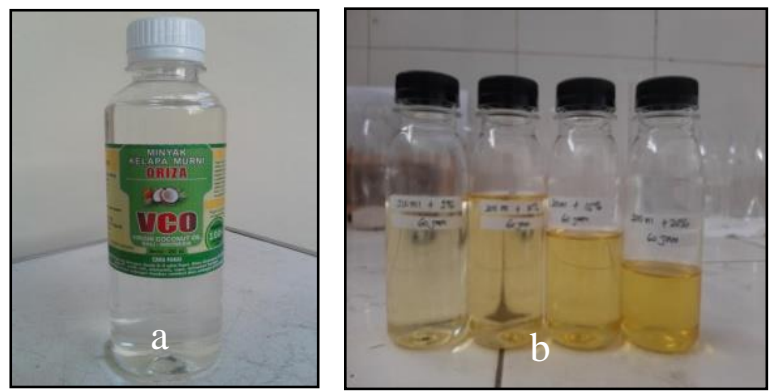

Gambar 4.6 (a) Gambar VCO SNI dan (b) Gambar VCO Hasil Penelitian

\section{KESIMPULAN DAN SARAN 5.1 Kesimpulan}

Dari hasil penelitian dan pembahasan dapat disimpulkan bahwa kondisi terbaik pada pembuatan virgin coconut oil menggunakan sari bonggol nanas yang sesuai Standar Nasional Indonesia (SNI 7381:2008) adalah proses pembuatan VCO dengan waktu inkubasi 24 jam dan konsentrasi ekstrak bonggol nanas $5 \%$, dengan hasil analisa yang didapat densitas 0,9150 $\mathrm{g} / \mathrm{cm}^{3}$, asam lemak bebas $0,133 \%$, bilangan asam 0,1870 , dan bilangan peroksida $1,8 \mathrm{meq} / \mathrm{kg}$. Hasil ini memunjukkan sudah memenuhi Standar Nasional Indonesia, dimana hal ini bisa menjamin mutu dari VCO yang telah dibuat untuk dimanfaatkan.

\subsection{Saran}

Diharapkan dari hasil penelitian yang telah dilakukan, maka peneliti menyarankan peneliti selanjutnya melakukan analisa organoleptik untuk bau dan rasa.

\section{DAFTAR PUSTAKA}

Effendi, Arnela Meida, Winarni, dkk.. 2012. Optimalisasi Penggunaan Enzim Bromelin Dari Sari Bonggol Nanas Dalam Pembuatan Minyak Kelapa. Skripsi. Jawa Tengah: Universitas Negeri Semarang.
Ishak, Amri Aji, dan Israwati. 2019. Pengaruh Waktu Fermentasi dan Berat Bonggol Nanas Pada Pembuatan Virgin Coconut Oil (VCO). Skripsi. Aceh: Universitas Malikussaleh.

Mardiatmoko, Gun dan Mira Aryanti, 2018. Produksi Tanaman Kelapa (Cocos nucifera L.). Maluku: Fakultas Pertanian Universitas Patimura.

Mesu, R. R., dkk. 2018. Pembuatan Virgin Coconut Oil (VCO) Dengan Menggunakan Enzim Papain Di Desa Gerbong Kecamatan Purwodadi Kabupaten Pasuruan Provinsi Jawa Timur. Skripsi. Malang: Sekolah Tinggi Penyuluhan Pertanian.

Palilingan, Septiany dan Meity Pungus. 2018. Produksi Enzimatis Virgin Coconut Oil (VCO) Dengan Enzim Bromelin Serta Pemurniannya Menggunakan Adsorben Zeolit. Skripsi. Manado: Universitas Negeri Manado

Perdani, Claudia Gadizza, Maimunah Hindun Pulungan, dkk.. 2019. Pembuatan Virgin Coconut Oil (VCO) Kajian Suhu Inkubasi dan Konsentrasi Enzim Papain Kasar. Skripsi. Jawa Timur: Universitas Brawijaya.

Ramadhani, F.A., 2010. Pengaruh Sari Buah Pepaya Muda (Carica papaya) dan Lama Pemeraman Terhadap Kualitas dan Kuantitas Minyak Kelapa (Cocos nucifera var. Viridis). Skripsi. Malang: UIN Malang.

Rampengan, V. F. 2006. Beberapa Karakteristik Virgin Coconut Oil yang Diolah Secara Fermentasi. Eugenia, 12(3), 229-234.

Rindengan dan Novarianto. 2004. Pembuatan dan Pemanfaatan Minyak Kelapa Murni. Jakarta: Penebar Swadaya.

Sari, E.P dan Andayani. 2009. Pembuatan Minyak Kelapa Murnin (Virgin Coconut Oil) Menggunakan Fermentasi Ragi Tempe. Skripsi. Surakarta: Universitas Sebelas Maret. 
Sari, Tuti Indah, Evy Herdiana, dkk.. 2010. Pembuatan VCO Dengan Metode Enziamtis Dan Konversinya Menjadi Sabun Padat Transparan. Skripsi. Sumatera Selatan: Universitas Sriwijaya.

Setiaji, B dan Surip, P. 2006. Membuat VCO Berkualitas Tinggi. Jakarta: Penebar Swadaya.

Sitompul, N.H.. 2017. Optimasi pH Dan Suhu Pada Pembuatan Virgin Coconut Oil Dengan Penambahan Ekstrak Bonggol Nanas (Ananas comosus). Skripsi. Sumatera Utara: Universitas Sumatera Utara.

Susanti, R., dan Fidia Febriana. 2017. Teknologi Enzim. Yogyakarta: CV Andi Offset.

Widjaja I.N.K, dkk.. 2016. Rendemen VCO (Virgin Coconut Oil) yang Diperoleh Dengan Penambahan Enzim Papain Dan Bromealin. Skripsi. Bali : Universitas Udayana.

Wuryanti. 2006. Isolasi dan Penentuan Aktivitas Spesifik Enzim Bromelin dari Buah Nanas (Ananas comosus). Skripsi. Semarang: Universitas Diponegoro.

https://id.natapa.org/difference-betweencoconut-milk-and-coconut-cream-126. Diakses pada tanggal 21 April 2021 pukul: 16.30 WIB

https://id.wikipedia.org/wiki/Santan. Diakses pada tanggal 21 April 2021 pukul: 17.15 WIB

https://id.wikipedia.org/wiki/Nanas. Diakses pada tanggal 5 Agustus 2021 pukul: 19.00 WIB

http://hortikultura.pertanian.go.id/?p=3266.

Diakses pada tanggal 5 Agustus 2021 pukul 20.00 WIB. 